\title{
A vida do livro e o livro da vida: escrita, leitura e biotecnologias
}

\author{
Leonardo Pinto de Almeida, ${ }^{I \star \star ~ C e ́ s a r ~ P e s s o a ~ P i m e n t e l l ~}$ \\ ${ }^{I}$ Universidade Federal Fluminense, Niterói, RJ, Brasil

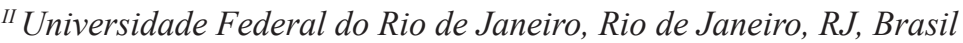

\section{Resumo}

O presente artigo tem como objetivo analisar as tensões estabelecidas entre a linguagem e o poder em duas searas aparentemente distintas: a genômica e o livro. Partindo da relação entre corpo, texto e poder, tomamos a história do livro e da genômica para estabelecer uma reflexão sobre a vontade de verdade e de ordem no seio da linguagem, a partir das imposições da melhor leitura do texto escrito e do código genético. Mostramos também que, tanto a literatura quanto a pós-genômica apresentam elementos que escapam à determinação de ordem, imposta pelas vontades de verdade e estabelecidas por relações de forças.

Palavras-chave: linguagem; poder; genoma; livro; interpretação.

\section{The life of the book and the book of the life: writing, reading and biotechnology}

\begin{abstract}
The present paper aims to analyze the tensions established between the language and the power in distincts fields: the genomic and the book. Leaving of the relation between body, text and power, we take the history of the book and the genomic to establish a reflection on the will of truth and the order, from the impositions of the best reading of the written text and the genetic code. We also show that, as much literature how much after-genomic they present elements that escape to the determination of order, imposed for the wills of truth and established by relations of forces.
\end{abstract}

Keywords: language; power; genomic; book; interpretation.

Ao tratar do corpo, das patologias e da saúde segundo noções oriundas da teoria da informação, como o código e a linguagem, as biotecnologias introduzem importantes questões para as ciências humanas. Se essas últimas pesquisas destacaram a imersão do|a homem|mulher ${ }^{1} \mathrm{em}$ um campo fundamentalmente distinto da natureza, como a História, a cultura ou a linguagem, os saberes biológicos atuais mesclam e atravessam tais domínios. Comparado a uma espécie de livro, o patrimônio genético tornou-se objeto de intensa mobilização tecnológica em escala internacional, conduzida pelo Projeto Genoma Humano, que teve como objetivo fundamental apreender seus caracteres, apostando na possibilidade de reescrevê-los.

É notável a presença frequente de comparações entre escritura e composição genética. François Jacob (1983, p. 277), renomado biólogo, destaca essa semelhança: "assim como uma frase constitui um segmento de texto, um gene corresponde a um segmento de ácido nucléico". Mas não é apenas como metáfora que nossa natureza genética é enviada ao domínio da informação. As fronteiras entre natureza e cultura são também atravessadas por práticas de poder. Com a noção de erro genético, as patologias são tratadas como problemas de interpretação, de decifração do código. Desta forma, pressupõe-se uma normatividade na natureza, onde as doenças genéticas seriam más interpretações do texto e a terapêutica deveria

\footnotetext{
*Endereço para correspondência: Universidade Federal Fluminense, Instituto de Ciências da Sociedade e Desenvolvimento Regional. Rua José do Patrocínio, 71, Centro - Campos dos Goytacazes, RJ - Brasil. CEP: 28010385.E-mail: leonardo.p.almeida@gmail.com, cesar.pim@hotmail.com

${ }^{1}$ As mulheres foram e ainda são invisibilizadas na história do pensamento. Esta forma de apresentação que se repetirá ao longo do presente texto é uma maneira de rompermos com este tipo de ocultamento.
}

restabelecer a ordem correta, de preferência antes que os desvios ocorram e as doenças se manifestem sintomaticamente (CANGUILHEM, 1995; ROSE, 2007).

Esse cenário não poderia deixar de repercutir fora do âmbito médico, despertando profundas inquietações às ciências humanas. Investigando os vetores com que a cultura moderna se apropria do corpo, David Le Breton (2007) toma a comparação entre vida e informação como ponto estratégico de um investimento político encampado medicamente. Se a medicina pode ser tomada simultaneamente como modo de normatizar os corpos e de cuidar do sofrimento, a singularidade contemporânea residiria no enfraquecimento da assistência ao sofrimento e no fortalecimento do controle.

Le Breton (2007) nota: não há vontade terapêutica ou caritativa, mas vontade de dominação. O secreto motor das investigações biomédicas, sobretudo no campo da genômica, ${ }^{2}$ reside no prazer de antecipar, de prever; nada mais do que ver o destino através de um corpo transfigurado em essência hereditária. Voltada para o deleite obtido pela observação dos códigos e dos mecanismos genéticos, a única característica retida pela medicina de seu passado clínico seria o diagnóstico. Entretanto aqui não há laços sólidos entre classificar a doença e curá-la e entre os tratamentos propostos e seus desdobramentos. Conhecer o risco genético e tomar medidas preventivas aparece como único exercício clínico possível em uma era devotada à censura da carne na experiência do corpo.

${ }^{2}$ Genômica é um ramo de investigação biológica, onde convergem biologia molecular e genética. Pode ser dividida em dois ramos: estrutural, no qual se tenta definir a sequência dos ácidos nucleicos que compõe o DNA, e funcional, no qual o modo como os genes são ligados ou desligados são investigados. A etapa mais contemporânea da pesquisa genômica, por vezes chamada pós-genômica, frisa aspectos não deterministas no funcionamento genético, criticando o modelo um gene-uma proteína. 
Podemos apontar a existência de uma doença incurável ou evitar o aparecimento de uma doença provável; lidar com a enfermidade na sua dimensão efetiva, quando há passagem do provável ao concreto, estaria fora do horizonte da medicina dos genes e moléculas.

$\mathrm{Na}$ análise do antropólogo, as relações entre corpo e poder estão bem realçadas. Pretendemos anexar outro domínio a essa relação: o texto. Não somente o corpo tem sido moldado, normatizado, tornado legível por diversas práticas, das quais a medicina é uma das mais fundamentais, mas também o texto escrito. $\mathrm{O}$ acesso ao texto, o modo de ler, a maneira de interpretá-lo são submetidos a regimes normativos que limitam as inúmeras possibilidades de se apropriar da escrita. Nas práticas de leitura, encontramos fenômenos bastante semelhantes àqueles encontrados pelos historiadores e antropólogos do corpo.

O presente artigo objetiva traçar uma reflexão sobre as proximidades e as diferenças entre o universo da escritura e a problemática ligada à genômica, a partir de reflexões sobre a norma. Tentaremos mostrar que os acessos ao texto escrito e ao código genético, aparecem orientados pelas noções de identidade e de ordenação. No entanto, observaremos também que tanto as críticas internas à genômica (a pós-genômica) quanto às recusas às palavras da tradição e às palavras reveladas, implementadas pela literatura moderna, criticam este caráter ordenado, destituindo-os de uma origem e de uma causa, seja um autor no caso do livro, ou o programa genético, no caso do corpo. Podemos ver que, no seio da ordenação genômica e do universo dos livros, existe algo que escapa ao determinismo, sustentado pela posição que reifica o substrato genético e interpretativo da vida e dos livros.

Assim sendo, para analisar o livro da vida e a vida do livro, aportando sobre o problema da ordenação e da identidade, observaremos as ideias de patrimônio cultural e biológico, através do texto e da leitura. Aproximaremos o texto escrito e o patrimônio biológico pela prática de leitura e sua relação com a norma.

\section{Disciplina, corpo e texto}

A regulação dos gestos, das posturas, da fisionomia e das expressões emocionais tem sido um fenômeno notado por antropólogos, filósofos, sociólogos e historiadores (MAUSS, 2007; HAROCHE; COURTINE, 1988; ELIAS, 1993; FOUCAULT, 2002). Antes que um aspecto do mundo natural, o corpo humano encontrar-se-ia cercado por práticas sociais que controlam não somente comportamentos adequados ao espaço público, como andar e falar, mas processos fisiológicos ligados à intimidade biológica: envelhecer, reproduzir, adoecer. Foucault (2002) destacou a dimensão política de tais investimentos sobre o biológico, estratégicos para a difusão do capitalismo e para a formação dos Estados modernos. Acompanhando a intuição de Marcel Mauss (2007) sobre a dimensão técnica na relação entre corpo e cultura, o filósofo frisa mais especificamente na modernidade a exacerbação do aspecto tecnológico da construção corporal.
A era moderna pode ser assim caracterizada pela organização e pelo uso de técnicas ${ }^{3}$ que investem em larga escala sobre o corpo, técnicas apropriadas a certa relação entre indivíduo, sociedade e poder. Ao contrário de um poder que inibe, anula, freia, esse tipo de investimento sobre o corpo aumenta suas habilidades. Trata-se de ampliar a produtividade do operário, o rendimento do aluno, a disciplina do soldado ou a saúde da população. A contrapartida desse incremento é a docilidade política, a conformidade do indivíduo a padrões exigidos pelas instituições em termos de aprendizagem e de produtividade. Em outras palavras, a modernidade não tanto pune ou marca o corpo, mas o disciplina, valendo-se do incremento das habilidades para diminuir a capacidade de contestação da ordem social.

Impor disciplina significa dispor no espaço: separar os trabalhadores em linhas de montagem, alunos em séries, soldados em filas a fim de observar, intervir, controlar. $\mathrm{O}$ projeto arquitetônico, elaborado no final do século XVIII por Jeremy Bentham, denominado Panóptico, representa a idealização de uma sociedade edificada sobre princípios disciplinares. Ainda que não tenha sido efetivamente construído, sua importância foi, ainda assim, considerável, inspirando diversas reformas realizadas em instituições já existentes, sobretudo, em prisões, hospitais e escolas. Neste projeto, propunha-se um prédio circular, alojando cada indivíduo em uma cela, vazada pela luz exterior, mas de forma que não seria possível ver o exterior. No interior dessa construção, ergue-se uma torre de observação. Nela está um vigia, nem sempre presente, mas que por sua distância estratégica do centro jamais se vê com clareza se realmente está lá. Portanto, a dúvida sobre estar sendo visto não pode ser dissipada, dúvida propositalmente induzida pela arquitetura, já, em si, uma peça do poder.

Organizar operários, alunos, prisioneiros, pacientes ou soldados no espaço se tornava ao mesmo tempo meio de conhecimento e reconhecimento de suas especificidades, de suas características singulares. A separação no espaço, em séries, filas ou quartos, significava ao mesmo tempo organização e classificação. Em outros termos, pretendia-se tornar possível saber quem o indivíduo era, tomando por base sua localização no espaço.

Entre a organização do corpo e a do texto talvez existam canais de comunicação pouco visíveis, mas nada desprezíveis. Detendo-se sobre a escrita e a leitura, Haroche (1992) realça semelhanças notáveis entre os procedimentos disciplinares aplicados aos corpos e aqueles aplicados sobre a gramática. Em ambos os domínios, trata-se, na opinião da autora, de individualizar, ou seja, fundamentalmente separar, evitando a ambiguidade, a confusão, a mistura:

Fica-se então impressionado pela analogia com processos arquiteturais utilizados, no fim do século XVIII, nos edifí-

${ }^{3}$ Foucault usa o termo técnicas disciplinares para designar procedimentos, nem sempre codificados, mas sempre presentes em instituições, de transformação do comportamento, dos gestos e da postura corporal. Ele distingue as técnicas utilizadas para controlar a natureza daquelas empregadas no domínio social. O controle da natureza é submissão da necessidade à liberdade humana, o controle social, pelo menos tal como se dá na modernidade, é jogo entre liberdades, supõe sempre um indivíduo dotado de mínimos requisitos para escapar à dominação. Nesse sentido, poder, embora vise à dominação, é distinto de violência. 
cios disciplinares; esses procedimentos de observação procuram tornar o indivíduo visível em seu corpo, seu comportamento, seus atos: eles se fundam sobre um princípio de visibilidade que isola cada sujeito de todos os outros. Tal visibilidade está ligada em profundidade à exigência de transparência e de legibilidade que isolam do mesmo modo o sujeito em seu propósito. A caça incessante à ambiguidade, à elipse (à falta), à incisa (ao acréscimo descontrolado) e, de maneira geral, a tudo que pode parecer uma zona de sombra nascida de uma ruptura na linearidade do discurso, participa dessa exigência de legibilidade (HAROCHE, 1992, p. 23).

A normatização da gramática fornece assim a chave para a compreensão dos vínculos entre corpo, texto e poder. Longe de ser um processo contemporâneo, os laços entre escritura e corpo, entre vida e informação já estavam estabelecidos pelos procedimentos disciplinares que organizam as legibilidades do corpo e do texto, mediante processos de ordenação. Tais processos limitam a proliferação do sentido, tornando reconhecíveis os indivíduos no espaço e o significado de um texto. Fixam, portanto, identidades.

\section{Norma, identidade e memória}

A criação de identidades, efeito dos procedimentos disciplinares podem também ser pensadas como atuação da memória. Não entendemos a memória como uma faculdade psicológica, existente no interior de nossas mentes, mas como um suporte material que serve de registro para determinados comportamentos. É o antropólogo Leroi-Gourhan (2002, p. 14) quem aproxima memória e programa:

Pode-se falar de uma memória específica, para definir a fixação dos comportamentos das espécies animais, de uma memória étnica, para assegurar a reprodução dos comportamentos nas sociedades humanas e, ao mesmo título, de uma memória artificial, eletrônica na sua forma recente e funcionando sem recurso ao instinto ou à reflexão, para garantir a reprodução de atos mecânicos encadeados.

A memória, nessa definição, equivale a um conjunto de determinações que asseguram que os comportamentos sejam não somente executados ocasionalmente, mas também repetidos, perdurando no tempo. Nesse sentido, tanto o instinto animal quanto as regras sintáticas da linguagem humana ou do programa de computador são espécies de memória. Entretanto, entre o|a homem|mulher e o animal existe uma diferença fundamental na determinação dos comportamentos. Enquanto a memória animal consiste em uma determinação interna, inscrita como programa biológico, no|a homem|mulher a memória assume formas externas, projetando-se na matéria. A linguagem seria a forma fundamental de exteriorização da memória que assegura a coesão do grupo humano, mantendo ativo um conjunto de comportamentos. Sua função aparece com o declínio das determinações biológicas que ocupam grande espaço no comportamento animal. Se as respostas às modificações no meio não são mais resguardadas por uma programação imediata como o instinto, a linguagem deve prover meios de resolução. Nesse sentido, ela constitui uma memória coletiva, um grande corpo de conhecimentos capaz de ser transmitido de geração para geração.

Fractal, Rev. Psicol., v. 29 - n. 3, p. 239-251, 2017
A importância da transmissão de conhecimentos implica na criação de modos de assegurar a eficácia do conhecimento já adquirido. Assim, a linguagem ganha uma dimensão material e recebe suportes para sua transmissão, passando de fala e da transmissão oral para inscrição e transmissão escrita. Destacando essa dimensão técnica, Lévy (1993), em As tecnologias da inteligência, mostra a importância da escrita como tecnologia que possibilita uma nova relação com o saber e o tempo.

Com o advento da escrita, há um distanciamento entre os discursos produzidos e as circunstâncias geradoras. Isto não acontecia na oralidade primária (primeira tecnologia da inteligência, apontada pelo autor francês), pois, o narrador e o ouvinte estavam envolvidos, na mesma situação, não havendo nenhuma separação entre receptor e emissor da mensagem, seja ela temporal ou espacial. Contudo, a escrita produz este distanciamento, esta separação. Com essa questão da distância entre autor e leitor, evidenciam-se algumas consequências: (1) o texto pode, agora, se tornar obscuro ao leitor; (2) cria-se, então, a necessidade de uma maneira própria de ler um texto, a interpretação, e sua teoria, a hermenêutica; (3) a exigência de verdade, pois o texto deve passar pelo crivo da análise e do exame; (4) a pretensão à universalidade, embutida sob o jugo das teorias.

Como podemos observar, com o advento da escrita se produz uma opacidade constitutiva na mensagem, devido ao distanciamento entre o emissor e o receptor, produzindo a necessidade da invenção dos métodos de interpretação e de produção de verdades universalizantes.

Essa dimensão técnica da linguagem nos permite estabelecer um plano comum às biotecnologias e à escritura. Em ambas, estamos lidando com modos de selecionar e de organizar a memória. No caso das tecnologias da vida, a questão é como se organiza o acesso e a leitura da memória genética, quais são as normas que governam a intervenção sobre os genes; no caso da escritura, como o sentido do texto é organizado, como sua leitura é normatizada. Nossa hipótese é que nos dois casos existem tensões entre um regime normativo, que implica na determinação de modos de acesso ao texto, seja genético ou escrito, e uma crítica ao sentido original do texto, que discute a presença de um autor ou programa que delimita os modos de leitura possíveis.

A escrita nasce assim como uma técnica de memória que visa possibilitar a transmissão de saberes, além de seu eixo espaço-temporal. A produção de verdades universalizantes da interpretação dos escritos está intrinsecamente relacionada à reificação do passado, apresentada em alguns momentos da história no Ocidente. ${ }^{4}$ Os suportes e as formas da escrita se modificaram ao longo da história de maneira a torná-la mais durável, e fácil de decifrar. Aqui se inicia a história que conduz à invenção

${ }^{4} \mathrm{O}$ conceito de invenção, encontrado ao longo da obra de Nietzsche e retomado por Foucault $(1994,1996)$, aponta para a ideia de que os fenômenos são inventados pelo entrecruzamento de forças no tecido sócio histórico. Esta compreensão pressupõe que os efeitos históricos que entendemos, como óbvios ou como se eles sempre existiram, fazem parte do processo de naturalização da verdade. Esta é a importância política do conceito de invenção, já que pressupõe que os estados de coisas são passíveis de mudança pela intervenção. O cerne do método genealógico está associado diretamente a essa discussão conceitual (ALMEIDA, 2009). 
do livro. Se este suporte acaba vingando é porque em sua direção se move a necessidade da espécie humana de solucionar problemas novos, contando com o auxílio de conhecimentos já adquiridos.

A escrita passou por diversas formas antes de se estabilizar no suporte do livro. Entre estas, podemos citar as Tábuas de argila, surgidas na Mesopotâmia há aproximadamente 6.000 anos, o papiro, popular no Egito, e o pergaminho. Do pergaminho, é desenvolvida uma técnica de dobradura em forma de caderno: o codex (KATZENSTEIN, 1986). O surgimento do codex se dá a partir da demanda do leitorado romano, ávido por livros, no período imperial em II d.C. A descoberta do pergaminho foi a grande virada. Esta foi uma grande revolução, pois o preço do codex era muito mais barato que o do volumen (rolo) romano, feito de papiro.

Cavallo e Chartier (1998) indicam inúmeras revoluções no seio das práticas que giram em torno do livro, sendo até mais importantes do que a própria revolução remetida ao nome de Gutenberg e sua fabulosa máquina, a imprensa. Dentre elas, estão: a mudança do rolo para o codex; a transformação do codex, como suporte para a textualidade, para a tela do computador; a progressiva aquisição da leitura silenciosa na Idade Média; e a mudança de uma prática de leitura intensiva da bíblia para uma leitura extensiva e livre no fim da idade Média, possibilitada pela proliferação dos livros no período do surgimento das novas universidade européias. No entanto, isso não reduz nem um pouco a importância da reprodutibilidade técnica de livros, proporcionada pela invenção da imprensa, cujo aumento significativo do acesso ao saber, proporcionou novas maneiras de se relacionar com a leitura.

Assim, em torno do livro gira toda uma produção cultural que está intrinsecamente ligada aos problemas relativos às ideias de patrimônio, de tesouro e de memória. Será a partir do eixo memória que nossa discussão aportará daqui em diante. A pergunta que nos guia é: qual é a relação com o passado que cada época trava a partir do livro? Cada cultura, produzindo valores diferentes em relação ao passado, introduz novas funções para o livro e para a memória.

\section{O livro, o passado, a memória: uma relação com a tradição?}

Para tomarmos o objeto livro em sua relação com o passado, analisaremos alguns marcos históricos da leitura no mundo ocidental, seguindo a reflexão de certos pensadores que examinam as práticas de leitura através da história.

De início, é bom sublinharmos a dinâmica das práticas que giram em torno da leitura. Chartier (1999), em $A$ ordem dos livros, mostra que a leitura se caracteriza por um movimento contraditório que estaria entre regras e constrangimentos, de um lado, e liberdade e rebeldia, de outro.

Ele mostra como a leitura se quer rebelde em seu ato propriamente dito. No entanto, com ela se instaura uma dialética entre a apropriação (rebeldia) e a imposição ou o respeito pelos protocolos da leitura. Neste texto, Chartier sublinha algumas maneiras de ordenação do universo dos livros, utilizadas entre o final da Idade Média e o século XVIII, como as comunidades de leitores, a figura do autor e as bibliotecas. Todas estas três categorias analisadas tinham como objetivo instaurar uma ordenação no seio do universo livresco.

Esta ordenação dos livros se debruça sobre as práticas de leitura, devido à preocupação em relação aos perigos referentes às perdas, ao excesso e à corrupção de textos. Esta preocupação, assinalada por Chartier (2001), se assemelha ao medo relativo à proliferação incessante do discurso, indicada por Foucault (2001c), em $O$ que é $o$ autor?, na nota esclarecedora de 1979. Nesta análise, ele sublinha o papel do autor como elemento ordenador da trama discursiva que funciona na tentativa de conter esta proliferação. O nome do autor seria atravessado por um caráter delimitativo, que impede a emergência da pluralidade de sentidos.

O autor torna possível uma limitação da proliferação cancerígena, perigosa das significações em um mundo onde se é parcimonioso não apenas em relação aos seus recursos e riquezas, mas também aos seus próprios discursos e suas significações. O autor é o princípio de economia na proliferação do sentido (FOUCAULT, 2001c, p. 287).

Então, podemos dizer que existe certo receio, certo medo dos excessos e da proliferação desordenada de sentido que guiam as reificações, as naturalizações interpretativas do universo discursivo, ligadas à produção escrita e, por consequência, livresca. Esta ordenação produz uma valorização do passado, da memória e da tradição interpretativa em detrimento da criação e da rebeldia constitutiva do ato de ler.

Para observarmos a relação do livro com o passado, devemos partir de uma análise histórica para assim concebê-la com a clareza que esta questão exige.

Comecemos então pelo surgimento da escrita na Grécia Antiga. Em seu artigo "Grécia arcaica e clássica", Svenbro (1998) mostra que a escrita alfabética apareceu na Grécia no século VIII a.C., porém ela ainda estava intrinsecamente atrelada à cultura oral.

Neste período, a escrita fazia o papel da memória, já que tinha por função a conservação. No entanto, não era qualquer conservação, pois ela estava ligada à memória social do povo em sua relação com seus heróis. Svenbro (1998) salienta com isso que a escrita na Grécia surgiu com o intuito de produzir a glória (kléos) dos heróis. Ela teria assim por função construir a permanência dos heróis na memória do povo.

Pois, para que serviria a "escrita muda" em uma cultura na qual a tradição oral se acredita capaz de assegurar sua própria permanência sem outro suporte além da memória e da voz dos homens? A resposta mais simples parece ser a seguinte: justamente para a produção de mais kléos, por exemplo, graças às inscrições funerárias, que garantiam uma nova forma de posteridade ao morto. Assim, a escrita teria sido utilizada pela cultura oral em uma perspectiva que não seria a de proteger a tradição épica (embora ela acabe por fazê-lo), mas, sim, a de contribuir para a produção de som, de palavras eficazes, de glória retumbante (SVENBRO, 1998, p. 41-42).

Fractal, Rev. Psicol., v. 29 - n. 3, p. 239-251, 2017 
Pelo meio deste tributo à oralidade, as práticas de leitura se manifestavam em voz alta. Podemos observar, antes de tudo, a relação entre os cidadãos gregos e a escrita. Primeiro, o suporte para a textualidade era o rolo. $\mathrm{O}$ rolo, em sua disposição material, mobilizava todo o corpo durante $\mathrm{o}$ ato de leitura. Segundo, a escrita era feita em scriptio continua (escrita sem separação de palavras). Esta forma de manifestação escrita causava inúmeros problemas de decifração do texto. Assim, para a melhor decodificação do texto, a voz surgia como instrumento imprescindível, possibilitando a compreensão por meio do ouvinte.

Deste modo, Svenbro (1998) sublinha que a leitura em voz alta era a predominante na Grécia antiga, pois o silêncio, em uma época atravessada pela oralidade, representava o esquecimento. No entanto, podemos observar ainda práticas de leitura silenciosa. Esta forma era marginal, já que necessitava, para sua aquisição, de uma técnica aprimorada que causava a interiorização da voz. Ela era adquirida por profissionais que liam com muita frequência, passando, através de sua prática, a ler cada vez mais baixo e mais rápido.

Em "Entre volumen e codex, a leitura no mundo romano", Cavallo (1998) analisa as práticas de leitura nos períodos monárquico, republicano e imperial no território romano, mostrando suas diferenças peculiares.

No período monárquico, a leitura era uma prática, exercida pelas classes dirigentes, que estavam relacionadas diretamente aos saberes divino e jurídico. Era uma prática restrita.

No entanto, há uma mudança no quadro da leitura, no período republicano, já que surgem novas práticas de leitura, associadas principalmente à constituição da literatura latina e da aquisição dos livros gregos (espólios de guerra). Nesta época, ocorre o florescimento de bibliotecas privadas e, por consequência, um aumento significativo do leitorado (pequena elite). A leitura passa assim a estar mais atrelada ao prazer do que a utilidade.

Entretanto, será com a difusão do alfabetismo no período imperial que surge uma nova classe de leitores, despreocupada com as qualidades editoriais do suporte, tendo a leitura como prática de divertimento pessoal. Neste momento da história romana, devem ser salientados três fatores importantes: a proliferação de bibliotecas públicas e privadas, a multiplicação produtiva de novos livros e a invenção do códex no século II d. C.

Deste modo, Cavallo (1998) mostra que, em Roma, a leitura foi bem difundida, passando por uma elite, constituída de profissionais, ligados ao direito e ao divino em sua prática de restituição da tradição (período monárquico), por uma pequena elite possuidora de bibliotecas privadas, frutos dos espólios de guerra contra a Grécia, cuja leitura estava mais associada ao prazer do que à utilidade do período anterior (período republicano) e por uma prática mais bem difundida associada ao alfabetismo crescente e à invenção do códex, constituindo um leitorado que buscava divertimento com a prática de leitura (período imperial).
Da passagem da época romana à Idade Média, se constituem práticas diferenciadas de leitura e de valorização da tradição e do passado. Em Roma, como na Grécia, a leitura em voz alta era a predominante e a scriptio continua era a forma material que o texto tomava corpo em seu suporte. A leitura, em Roma no seu último período histórico, era uma leitura prazerosa, despretensiosa, recreativa, exercida pelo meio dos variados textos produzidos. Assim, a leitura era uma leitura extensiva. Com a passagem para a Idade Média, a leitura se manifesta de forma muito diferente, já que no início deste período, ela é concentrada, em voz baixa, orientada, normativa, se debruçando sobre a meditação de livros seletos, associados ao Direito e, principalmente, à Sacra Scriptura. Por este fator seletivo da leitura, ela se constituiu como intensiva em relação à sua prática.

$\mathrm{O}$ início do período medieval foi marcado por uma forte relação com o sagrado. A leitura orientava-se para o aprendizado ético dos princípios cristãos. As práticas de leitura, de escrita e de cópia se manifestavam em um ambiente religioso. A leitura era uma prática associada ao clérigo. A leitura monástica se debruçava sobre a Sacra Scriptura e tinha o caráter intensivo, já que sua prática era repetitiva e incansável na busca da decifração da verdade divina. Ela se caracterizava assim pela busca do conhecimento de Deus e da salvação da Alma, fundamentada em uma profunda meditação sobre o texto.

Parkes (1998), em "Ler, escrever, interpretar o texto, práticas monásticas na Alta Idade Média", traça alguns parâmetros de comparação das práticas de leitura na Antiguidade Greco-Romana e na Idade Média. Na Antiguidade, a leitura era em voz alta e sua escrita era tributária da oralidade. A escrita conservava a memória dos heróis, como já sublinhado antes com Svenbro. Já no início da Idade Média, o passado era tratado com certa densidade. A leitura direcionava sua atenção aos escritos do passado. Ela era tributária das obras antigas. Era uma leitura de reverência e de decodificação. A leitura silenciosa adquirida na Idade Média, segundo Parkes (1998), foi fruto de uma nova postura frente à escrita.

Quanto mais a escrita era percebida como suporte de transmissão das autoridades do passado (e, na Idade Média, esses textos irão usufruir de maior autoridade para mais pessoas do que no passado), menos ela era entendida como um simples arquivo da palavra falada (PARKES, 1998, p. 106).

Após o século VII, a língua latina passou a ser entendida como uma "linguagem visível", já que no entender medieval as palavras faziam o leitor ver aquilo que elas designavam. Esta nova atitude frente à escrita ajudou nas mudanças das práticas de leitura que se diferenciavam, deste modo, do tributo à palavra falada observável na Antiguidade.

No entanto, a scriptio continua permanecia como forma de materialização do texto em seu suporte. Foram os escribas anglo-saxões, devido à sua própria dificuldade na compreensão do texto latino, que trabalharam para constituir a padronização relativa à separação de palavras, que 
somente foi estabelecida no século XII. Esta foi a inovação crucial ocorrida na Idade Média, já que modificou as práticas de escrita, de cópia e, consequentemente, de leitura.

Os copistas pararam de usar a escansão oral durante seu trabalho, tornando-se mais visual. Os escritores passaram a usar da composição manuscrita, deixando de lado o uso dos escribas. Assim, a escrita, antes da padronização, era atravessada por uma "ausência de privacidade". O fato mais curioso, consequência direta disto, foi a proliferação de escritos eróticos neste período medieval.

Saenger (1998) afirma que essa "privacidade medieval", tanto na prática escrita quanto na apropriação leitora, possibilitou o surgimento de uma problematização dos poderes representados pela Igreja e pelo Estado, através da "ironia" e do "cinismo". Porém, em contrapartida, ela propiciou uma maior intimidade do leitor em sua relação com Deus, mediada pela Sacra Scriptura.

Neste período da Idade Média, ocorre uma renovação intelectual derivada do surgimento das escolas e universidades europeias. Hamesse (1998) aponta que uma nova forma de abordar o livro passa a conceber as práticas de leitura e de escrita como trabalho intelectual.

Podemos sublinhar aqui, uma forte mudança nas práticas de leitura. No início da Idade Média, a leitura monástica era intensiva, porque se debruçava na Sacra Scriptura, buscando uma profunda compreensão da palavra divina. Já no período relativo ao surgimento das escolas e das universidades europeias, a leitura escolástica era extensiva, rápida e fragmentária, buscando a restituição da tradição associada à noção de autoritactes.

Os autoritactes foram um dos instrumentos mais usados pelos estudiosos, ajudando-os no acesso direto ao conhecimento útil. Ele designava textos ligados à tradição, remetidos ao nome de seu autor. Ele era o próprio argumento de autoridade, usado pelos medievais, nos combates intelectuais sustentados pela prática do disputare (a arte da discussão).

Por causa da dificuldade de compreensão dos originais e pelo alto preço do livro, os medievais inventaram os florilégios (comentário medieval). Estes foram inventados para o melhor uso dos autoritactes, já que eram compilações de trechos importantes da obra de certo autor, ou de certa tradição. Ele teve grande sucesso entre os acadêmicos, tanto alunos, quanto professores.

A leitura dos florilégios sustentava uma relação com o passado. Eles apontavam para uma leitura de reverência e de restituição da tradição de escolas de pensamento ou de autores. No entanto, ela colocava um problema crucial para o pensamento, já que a seleção tende normalmente a deformar a obra escolhida. Foi, justamente, esta a crítica fundamentada pelos humanistas ao comentário medieval. Os humanistas abandonaram o uso dos autoritactes em nome da ratio e fundamentaram outra forma de se relacionar com o passado, pelo meio da volta aos originais e pela construção do comentário humanista.

No período humanista, o trabalho intelectual sofre modificações derivadas de suas críticas ao escolasticismo. A crítica humanista aos autoritactes e, consequente- mente, aos florilégios os ridicularizava em nome da volta aos originais. Grafton (1999) mostra que esta crítica se calcava sobre os problemas ligados ao conteúdo e à forma do comentário medieval.

Em relação ao conteúdo, os humanistas criticavam o utilitarismo vigente e o caráter seletivo que suscitavam a deformação das escolas de pensamento por ele abordadas. Já, em se tratando da forma, eles indicavam que a maneira de editoração e o uso das letras góticas nos florilégios não eram agradáveis ao leitor.

Por causa disso, os humanistas usaram letras mais agradáveis e publicaram seus livros em diversos tamanhos: os grandes fólios (in-fólios e in-quartos) que serviam para presentear e para a instrução e, os menores (in-oitavos), que eram mais portáteis e usados para distração. Grafton (1999) salienta que o padrão do livro humanista era o portátil, mais prático e mais elegante do que o livro medieval.

A invenção de Gutenberg, a imprensa, segundo Cavallo e Chartier (1998), não constituiu uma grande revolução na história do livro, já que existe certa continuidade entre o livro manuscrito e o livro impresso. Os livros não se modificaram muito, mas a imprensa possibilitou a produção de cópias em série e, consequentemente, uma maior circulação de livros do que antes.

No entanto, sucede uma mudança de um sistema artesanal para um sistema industrial na produção dos livros. Os livros passam a ser um produto de massa. Sua forma parou de ser escolhida pelo comprador, para se tornar uma escolha do empresário, tornando-o um objeto impessoal.

Chartier (1999, p. 8) afirma, em A ordem dos livros, que "o livro sempre visou instaurar uma ordem". Os humanistas, em sua crítica aos florilégios medievais e a sua concepção de um novo comentário, tentaram impor a sua. Este comentário tinha como objetivo organizar os textos antigos, pelo meio de um uso moderno do mesmo. Assim, como os comentários medievais, o comentário humanista, em sua volta ao passado, constituiu uma tradição interpretativa que foi reificada por sua prática de modernização dos escritos antigos.

Por conseguinte e paradoxalmente, o texto humanista tinha retornado à posição das autoritactes medievais. Competentes, suas glosas eram menos opacas que as medievais [...]. O novo comentário, no entanto, aprisionava e forjava o texto de forma tão poderosa quanto o antigo. Adornado com a exegese humanista, o texto parecia importante não por si mesmo, mas também por novamente estar ligado a um sistema de aprendizado e de interpretação (GRAFTON, 1999, p. 32).

Tomando a análise foucaultiana, encontrada em "A Linguagem ao Infinito" (FOUCAULT, 2001b), observamos que, tanto o comentário medieval, quanto o humanista, apresentavam-se, como práticas de escrita, inseridas em uma tradição.

Tradição em que a religião ainda usufruía de grande força. A Reforma e a Contra-Reforma foram tentativas de problematização e de restabelecimento do edifício religioso. Entretanto, seria, no século XVII e XVIII, que as religiões e as convenções sofreriam as críticas mais fervorosas. 
No entanto, antes de entrarmos nos questionamentos, relativos a esse período histórico, à moral vigente, à tradição e à verdade divina, observemos ainda um fenômeno importante concomitante à proliferação de livros em série, proporcionada pela imprensa: a ciência moderna.

Como assinalado anteriormente, o surgimento da imprensa modificou a divulgação do conhecimento. Essa invenção entrou em afinidade com outra série de acontecimentos na cultura ocidental: a constituição da ciência moderna, a valorização do estudo da natureza, a ampliação da intervenção sobre os corpos.

As obras científicas e políticas da Antiguidade Greco-Romana foram recuperadas, no período humanista, e a teologia medieval perdeu grande parte de seu espaço. A ciência proliferou-se justamente na mesma época em que a imprensa foi inventada. O passado foi retomado sob a forma do saber e sobredeterminada pelo princípio da ratio (e não mais direcionada pela verdade divina e pelos autoritactes) para a produção de um conhecimento científico.

$\mathrm{Na}$ medida em que esse saber foi produzido, a tradição, a fé e a superstição foram cada vez mais criticadas. No entanto, a prática científica abriu espaço para a constituição de uma nova tradição, um passado recente construído pela verdade científica. A reificação da verdade está intrinsecamente ligada à naturalização e à construção de tradição. Daí, o caráter ascético da ciência e o niilismo passivo, derivado da prática científica (ALMEIDA; DO EIRADO, 2003).

No século XVIII, o panorama político se torna o evento decisivo onde o sentido da escrita foi modificado. Presenciou-se a utilização dos manuais, dos livros didáticos e das obras clássicas ligadas à origem de um país, publicados no idioma nacional, para criar a noção de uma unidade nacional constituída por valores comuns, ligada ao conceito de Bildung, como salienta Eagleton (2005, p. 16-17), neste trecho de $A$ ideia da cultura:

Para que o estado floresça, precisa incutir em seus cidadãos os tipos adequados de disposição espiritual; e é isso o que a ideia de cultura ou Bildung significa numa venerável tradição de Schiller a Matthew Arnold. [...] A cultura é uma espécie de pedagogia ética que nos torna aptos para a cidadania política ao liberar o eu ideal ou coletivo escondido dentro de cada um de nós, um eu que encontra sua representação suprema no âmbito universal do Estado.

Já no campo social, a normatização da gramática e da escola possibilitaram o emprego da educação como tecnologia para a formação de um público letrado, onde o indivíduo foi normatizado e incitado a desenvolver suas próprias potencialidades a partir da leitura (SLOTERDIJK, 2000).

A relação com o passado foi assim modificada, pois a partir da institucionalização da educação, o livro foi usado para o progresso, para um projeto político que visava, sobretudo, o futuro, que se dava frequentemente pela modificação das tradições. Da mesma forma, nos diários íntimos o que importava era o acontecimento presente e efêmero.

Enquanto, em parte da Idade Média, a leitura se dava como rememoração das lições para salvar a alma, na modernidade, o objetivo é aprender para se tornar mais hábil e aperfeiçoar o Estado. Isso ocorre, justamente, devido ao sentimento de descontinuidade entre a vida dos|as homens|mulheres e a dos|as deuses|as, percebidas nas vivências cotidianas a partir do século XVII, como salienta Trousson (1996), em seu texto sobre a literatura libertina.

Esta descontinuidade entre homens|mulheres e deuses|as foi a vivência que deu origem à experiência moderna, atrelada aquilo que Nietzsche (2001) chamou, ao longo de sua obra, de Morte de Deus. Este acontecimento modificou a maneira de nos depararmos com a escrita e, por consequência, com o livro e sua relação com a tradição e o passado.

Esta nova forma de escrita, Foucault a nomeou de literatura, em inúmeros de seus textos dos anos 60 e 70, como "A loucura, a ausência da obra" (1999a), "Loucura, literatura, sociedade" (1999b), "A loucura e a sociedade" (1999c), "Linguagem e literatura" (2000), "Prefácio à transgressão" (2001a), e "A Linguagem ao Infinito" (2001b).

Para autor francês, a literatura estaria intrinsecamente ligada à transgressão e à recusa radical de toda ideia de tradição. Foucault (2001b), munido das ideias da morte de Deus e da invenção, construiu teoricamente uma distinção entre as manifestações do ser da linguagem anteriores e posteriores à modernidade, constituindo, deste modo, a sua forma analítica entendida, sob o nome de ontologia da literatura, que compreende o ser da linguagem como repetição, e a literatura como uma de suas manifestações.

A literatura se caracterizaria como uma nova forma de manifestação do ser da linguagem, em decorrência das consequências diretas da morte de Deus - acontecimento que trouxe à luz a modernidade. Segundo Foucault, as obras anteriores à modernidade (as obras de linguagem) se caracterizariam pela reduplicação, pela rememoração, da Palavra Divina e da Tradição que se atualizam no movimento da escrita, como elementos transcendentes ao seu ato. Já a literatura, por ter nascido em um período em que a palavra divina e da tradição se encontram esvaziadas, se caracteriza pela própria recusa radical de toda ideia de tradição.

Na escrita literária, não existem elementos transcendentes que se atualizariam em seu ato. Ela é entendida como um ato imanente que reduplica a relação da linguagem com o vazio da morte em toda sua radicalidade, devido à vivência da finitude humana tão evidente com a morte de Deus.

A literatura estaria longe de ser uma rememoração, um relato como a obra de linguagem, já que não haveria nada transcendente ao seu ato de escrever. Deleuze (1997, p. 12), em Crítica e Clínica salienta isso com contumácia "Escrever não é contar às próprias lembranças, suas viagens, seus amores e lutos, sonhos e fantasmas". Escrever literatura não seria "escrever sobre" algo - como na obra de linguagem -, mas "escrever com" o próprio vazio da linguagem.

A importância da questão da finitude e da existência se torna evidente com o pensamento de Milan Kundera. Em L'art du roman (KUNDERA, 1986), o autor tcheco se aproxima do pensamento deleuziano ao afirmar o caráter anti-filosófico ${ }^{5}$ da literatura. Segundo ele, a literatura seria

${ }^{5}$ Colocamos em evidência, em Escrita e leitura (ALMEIDA, 2009), que esta imagem da literatura, como anti-filosófica por excelência, aponta para certas imagens da filosofia que o autor tcheco tinha em mente, mas que não congregam todas as filosofias existentes Seriam elas: a sistematicidade, a seriedade e o dogmatismo. 
um espaço de exploração intensiva das possibilidades da existência, surgida, evidentemente, do peso incomensurável da finitude e pela recusa do dogmatismo e da seriedade. É, através do humor, que a literatura colocaria em xeque as verdades que nos atravessam e nos direcionam em nossas relações com o mundo, com as palavras, com outros|as homens|mulheres e com nós mesmos hodiernamente.

O humor e o anti-dogmatismo da literatura possibilita uma linha de escape do determinismo interpretativo, ocasionada pela ordem dos livros. No entanto, observamos uma tensão entre isto que escapa a toda tradição na experiência literária e a tentativa de captura e determinação interpretativa da literatura, feita pela cultura e pela crítica literária em seu trabalho de interpretação (ALMEIDA, 2009).

$\mathrm{Na}$ história do livro, constatamos historicamente inúmeros povos que implementaram queimas de livros por entenderem que a possibilidade do livro modificar seus cidadãos causaria perigo ao Estado. O biblioclaustro nazista, as censuras aos livros comunistas nos Estados Unidos, o caso Salman Rushdie, o confisco e a queima de livros nos países Bálticos, na revolução cultural da China, e na ditadura da Argentina, são apenas alguns exemplos de destruição de livros fundamentada na política de extermínio de grupos que colocavam questão para a sociedade e o regime.

Não é à toa que vemos regimes autoritários darem tanta importância aos livros como inimigos da ordem, pois a experiência de ler possibilita a transformação de nossas vidas, pensamentos e convicções.

Para darmos um exemplo sobre este fato, evocamos o romance de Umberto Eco (1986), O nome da Rosa. Neste livro, toda uma série de crimes, culminando na queima da biblioteca do convento, está relacionada ao livro sobre o riso de Aristóteles que estava supostamente perdido. Ele estava escondido, porque o riso poderia trazer a desordem.

$\mathrm{O}$ riso e o humor tem o poder de nos modificar e, em uma dada instância, ao nos disponibilizar de elementos politicamente questionadores do status quo. A literatura está ligada a isto, já que tem em sua experiência a possibilidade de mudar nossas convicções. Daí, o seu perigo.

No entanto, uma progressiva normatização da transgressão literária ao longo dos séculos XIX e XX sucede. No século XIX, como resistência e sintoma à recusa ao passado e à tradição, motor da própria literatura moderna, observa-se o surgimento de museus que devem preservar os tesouros culturais, com a função de manutenção de uma memória. Interessante é que o princípio que rege a relação entre o aparecimento dos museus e a memória se aproxima do princípio de preservação de livros, como patrimônio de um povo, associada às bibliotecas nacionais que florescem ao longo da história do livro no Ocidente (CHARTIER, 1999). As bibliotecas e os museus tem o intuito de, em nome de um conceito de cultura, preservar a memória que glorifica a nação.

Esta valorização da memória do povo reificada pelos museus está associada tanto ao conceito de civilização, já que o imperialismo alimentou por deveras o conjunto de tesouros destes mausoléus da cultura que são os museus, quanto no conceito de Kultur, pois a valorização da arte se vale, neste período, através de uma pedagogia do ver, que proporciona ao grande público o encontro com obras importantes de nossa cultura.

Ao mesmo tempo, a interpretação dos textos e do passado cultural foi transformada em ciência. Surgem a Etnologia preocupada com o sentido que as outras culturas atribuem à realidade e a Hermenêutica, disciplina filosófica que visa decifrar o sentido dos textos sagrados. A experiência da linguagem muda radicalmente: de instrumento onde o mundo foi espelhado, a palavra torna-se instituinte de um regime de pensamento, na medida em que as palavras têm seu sentido alterado na História e cada interpretação marca a possibilidade de uma vitória de um modo de vida sobre outro. Vive-se uma crise do sentido na filosofia e na linguística: a palavra não é canal ou instrumento do sentido, mas violência imposta à realidade, a escrita é comparada à obra estética, o signo à interpretação (FOUCAULT, 1987).

\section{Linguagem, corpo e morte}

O surgimento da literatura moderna é contemporâneo de uma ampla reorganização dos saberes. Seu aparecimento pode ser considerado índice de uma transformação mais geral no modo de relacionar as palavras às coisas ou de ordenar a realidade. Foucault (1987) descreve a literatura como acontecimento, ou seja, abertura de possibilidades a partir do rompimento com o modo historicamente anterior de organizar a realidade, que funcionava nos séculos XVII e primeira metade do século XVIII. Apesar de sua diversidade, as ciências e os sistemas filosóficos desse período estiveram pautados sobre certos princípios gerais, a partir dos quais se formava a certeza de que o sujeito e o mundo exterior seriam transparentes ao pensamento, desde que seus elementos (plantas, animais e riquezas, no caso do mundo exterior, signos e ideias no caso do mundo interior) fossem estabelecidos em séries em que as falsas semelhanças pudessem ser dissipadas. Um bom exemplo dessa configuração epistemológica é o cogito cartesiano, baseado na possibilidade de apreender tudo o que o sujeito é a partir do pensamento.

Ao final do século XVIII, a configuração dos saberes se altera. $\mathrm{O}$ modo como a linguagem se articula com as coisas é remodelado, implicando na transformação das formas de se classificar o corpo e o mundo natural. Um domínio particularmente afetado é o da medicina. Antes do século XIX, as doenças eram vistas segundo a configuração epistemológica da História natural, ou seja, consideradas espécies puras que o olhar médico deveria enxergar através do corpo do doente. Dessa perspectiva, o corpo do indivíduo exibia uma manifestação imperfeita de uma essência patológica. Os médicos se preocupavam de tal modo com a forma pura da doença que preferiam diagnosticar e curar na casa do doente, ao invés de fazê-los no hospital, já que se acreditava que as doenças evoluíam e se tornavam mais complexas de acordo com o progresso técnico. $\mathrm{O}$ domicílio representava uma forma ligada às origens arcaicas de convivência humana e nele deveria ser feita a classificação das enfermidades. 
O corpo, entendido enquanto superfície individual e volume orgânico, começa a ser valorizado apenas a partir do século XIX. Não somente na medicina, mas em uma série de outros domínios, a obsessão classificatória tem seu rumor progressivamente silenciado. Em sua obra dedicada aos saberes acadêmicos que proliferaram ao longo do século XVII e XVIII, Foucault (1987) define esse momento como crise da representação, datando-o num momento mais avançado da modernidade, no qual o estudo da vida, do trabalho e da linguagem abrem espaço para que as ciências humanas integrem o novo campo de conhecimentos surgido do século XIX.

Para que se compreenda melhor esse novo campo de conhecimentos, é crucial tomarmos em nossa análise a estratégia da representação que organizava os saberes ocidentais, especialmente na França e Inglaterra, até o século XVIII, sem no entanto, questionar seus limites e o sujeito do conhecimento. Em outros termos, mundo e sujeito, cuja correspondência estava assegurada, deixaram de ser transparentes ao pensamento e se espreita a suspeita de que nem tudo é representável. O próprio pensamento passa a ter regiões de sombras, como a linguagem, a herança animal ou o Inconsciente, que limitam o conhecimento do sujeito por ele mesmo. Isso implica que o principal meio de tornar o mundo representável, "a linguagem", deixa de ser um simples instrumento para o conhecimento e passa a deter um poder de interpretação, onde o que é visto deve ser tratado como signo ou indício de uma realidade que escapa ao olhar e que contém certa opacidade.

Deste modo, o corpo para a medicina do século XIX torna-se o lugar onde há indícios que devem ser decifrados para se entender a causa e a origem das patologias. A anatomia, antes relegada a segundo plano nas práticas diagnósticas durante o século XVII, é deslocada para primeiro plano, atuando como principal instrumento na sondagem das porções corporais que determinam os sintomas. A dissecação anatômica implica, assim, na ordem científica, o jogo entre superfície e profundidade que faz do corpo uma espécie de arquivo legível e decifrável, um conjunto de signos que indicam outra realidade.

O poder interpretativo da linguagem abre espaço para um acontecimento, segundo Foucault (1987), inédito: o conhecimento e o controle científico do|a homem|mulher possibilitado pelas ciências humanas. Isso significa que o modo da medicina entender o corpo e a doença participa de uma dinâmica muito mais ampla, onde se pode notar o surgimento de um modelo de compreensão baseado em índices ou sinais (GINZBURG, 2007). Percebe-se a presença desse modelo tanto em Freud, que remete os sintomas a uma intenção inconsciente, mas também em métodos adotados para o reconhecimento de uma obra de arte, assim como em fichas de identificação de criminosos que serviram de recurso para os modelos de vigilância panópticos, adotados pelos Estados Nação recém surgidos no século XIX. Tal convergência pode ser notada no elogio feito por Freud (apud GINZBURG, 2007, p. 147) aos métodos empregados por Morelli para certificar a autenticidade de pinturas:

Fractal, Rev. Psicol., v. 29 - n. 3, p. 239-251, 2017
Ele (Morelli) chegou a esse resultado prescindindo da impressão geral e dos traços fundamentais da pintura, ressaltando, pelo contrário, a importância característica dos detalhes secundários, das particularidades insignificantes, como a conformação das unhas, dos lobos auriculares, da auréola [...]. Creio que seu método está estreitamente aparentado à técnica da psicanálise médica. Esta também tem por hábito penetrar em coisas concretas e ocultas através de elementos pouco notados ou desapercebidos, dos detritos ou refugos de nossa observação.

Notando a convergência entre medicina e ciências humanas, Foucault atribui ao pensamento médico um papel fundamental no conhecimento do|a homem|mulher. Em sua perspectiva, a medicina clínica do século XIX sobressai por inserir pela primeira vez os atributos particulares, como cores, linhas, formas e texturas modificáveis no decorrer do tempo, sob escrutínio científico. Antes de seu aparecimento, permanecia em vigor o antigo anátema de Aristóteles de que não há ciência do indivíduo. O que torna o indivíduo objeto possível para a ciência é a articulação sólida entre doença e morte. Os médicos do século XIX não pensam que o|a homem|mulher morre porque adoece, mas que somos seres finitos, mortais e por isso adoecemos. A doença é manifestação visível da relação fundamental travada pelo ser vivo com a morte: "não é porque caiu doente que o homem morre; é fundamentalmente porque pode morrer que o homem adoece" (FOUCAULT, 2004, p. 171).

A posição fundamental da morte também se manifesta nos métodos de investigação médica, pois é através da abertura do cadáver que as leis orgânicas são reveladas. A morte não é mais o terreno onde o esforço científico cessa de avançar, mas o ponto em que a verdade se abre ao conhecimento. Verdade que se articula com o corpo e seus sinais, onde os indivíduos passam a entender a si mesmos através da divisão entre saúde e doença. Se a morte é observada pelo prisma científico, a medicina, e não mais a religião, determina o que devemos fazer para viver bem. É diante da ameaça de morte e da promessa médica de seu adiamento que desejamos ser indivíduos normais, com boa saúde e tememos o adoecimento.

A experiência da finitude aberta pela medicina moderna se alinha com a experiência literária do mesmo período histórico. No século XIX, escritores e escritoras, como Hölderlin, buscam esclarecer a condição humana, através da relação do indivíduo com a morte. $O$ tema do afastamento dos|as deuses|as serve para marcar uma relação fundamental com a finitude, onde a passagem do tempo e a individualidade não são traços defeituosos do|a homem|mulher, mas definem simultaneamente limites e poderes. A finitude moderna não é mais, como pensava a idade clássica, mera negação do infinito, mas condição histórica através da qual se abre o acesso à verdade e se torna possível transformar tecnicamente a natureza.

A morte aparece também em um contexto de reflexão sobre a linguagem sob a forma do tema do desaparecimento do autor. Tema comum a Nietzsche e a Mallarmé, mas enquanto o primeiro mantém ativa a pergunta sobre quem fala em suas investigações sobre a origem da mo- 
ral, o poeta francês delega a autoria da linguagem e do discurso à própria palavra (FOUCAULT, 1987). Como se não fôssemos autores|as da linguagem, mas submissos|as e falados|as por ela. Essa experiência da linguagem vigente na literatura e na reflexão filosófica, no entanto, avança para uma conclusão mais radical sobre o indivíduo do que a medicina e as ciências humanas. Agir medicamente sobre a doença implica um conhecimento do|a homem|mulher determinado pela necessidade de conhecer as particularidades dos indivíduos, a história passada através de métodos de anamnese. A morte e a doença conduzem o olhar médico para o indivíduo. Já a reflexão sobre a linguagem torna o|a homem|mulher uma forma provisória, uma identidade transitória, um efeito de sentido. Enquanto a linguagem atravessa o|a homem|mulher, a doença conduz ao indivíduo.

\section{Doença, código e informação}

No século XX, as relações entre linguagem e doença continuam a se intensificar. A concepção do corpo como arquivo legível se radicaliza através da aplicação da teoria da informação à fisiologia. Essa teoria tem em Claude Shannon um de seus expoentes, sendo desenvolvida na primeira metade do século XX. Trata-se de uma concepção instrumental da linguagem, onde se visa somente comunicar, tornar transparente uma mensagem transmitida por uma fonte e destinada à outra pessoa ou dispositivo técnico. Nessa concepção, há cinco termos importantes: a "fonte", que produz uma mensagem, o "codificador ou emissor", que transforma a mensagem em sinais, o "canal", o meio utilizado na transmissão da mensagem; o "decodificador ou receptor", que reconstrói a mensagem a partir dos sinais e, finalmente, a "destinação", pessoa ou aparelho ao qual a mensagem é destinada (MATELLART, A.; MATTELART, M., 2008). Muito longe se está da experiência de abertura do mundo relacionada pelos filólogos do século XIX à linguagem. Eles atribuíam à linguagem o papel de formar uma visão de mundo, de modo que traduzir um livro ou qualquer escrito era uma tarefa ética, pois colocava em contato duas formas de agir e compreender o mundo totalmente diferentes (HABERMAS, 2000).

A partir da concepção da linguagem como atividade puramente instrumental, um novo entendimento das patologias passa a ser moldado. Com ela, surge a noção de doença, como erro de informação, causada por codificações ou interpretações incorretas. A noção se elabora em três tempos. O primeiro passo concerne à fisiologia de Cannon, divulgada por volta de 1930, na obra "A sabedoria do corpo", onde é exposto o conceito de homeostasia, ou seja, a necessidade de um constante restabelecimento das funções da vida orgânica através de sistemas de autorreguladores (CANGUILHEM, 1995).

Nesse estágio de elaboração, a concepção de erro não aparece explicitamente, mas a base de seu aparecimento está preparada, ou seja, o entendimento do corpo como um sistema dotado de inteligência capaz de corrigir abalos provocados por perturbações provindas do meio exterior. É também uma fase nas quais as analogias entre organis- mos e sociedades estão muito presentes. Acontece que Cannon, ao utilizar o termo regulação, acolhe um conceito elaborado primeiramente pela fisiologia, mas sob outra semântica, já apropriado pela política. Por isso, o biólogo faz das crises políticas estágios intermediários, sucedidos por um equilíbrio tomado como ideal normativo da sociedade. O corpo recebe, assim, uma espécie de inteligência que, como nota muito bem Bernuzzi Sant'Anna (2001, p. 70), "não se concentra apenas no cérebro".

$\mathrm{Na}$ etapa seguinte, desenvolvida por volta de 1950, tal inteligência é acolhida de forma mais crítica: o corpo pode ser sábio, autorregulado, mas comete enganos com muita frequência. Canguilhem considera Hans Seyle e Reilly os responsáveis por essa elaboração. Ambos os pesquisadores conferem pouca importância à localização espacial do agente patogênico, dando maior ênfase à noção de perturbação de funções. $\mathrm{O}$ trabalho de Seyle versa sobre síndromes patológicas não específicas, nas quais os sintomas são gerados pela reação adaptativa a qualquer tipo de estimulação brusca, seja interna, como uma descarga hormonal, externa, como um traumatismo, ou psíquica, como uma emoção reiterada. $\mathrm{O}$ organismo adoece pelo prolongamento de seu estado de prontidão. De início, tais reações visam um estado de defesa, uma restauração do equilíbrio, no entanto, a busca constante desse estado gera um esgotamento.

Com essas constatações, a noção de sabedoria do corpo é discutida, pois é o próprio sistema de autorregulação que conduz às síndromes estudadas por Seyle. Intuitivamente, os patologistas começaram a se referir a esses fenômenos como erros fisiológicos, atribuindo ao organismo uma espécie de finalidade ou de cálculo que não foi bem realizado. Nessa segunda etapa, o termo "erro" já aparece explicitamente, ainda que sob forma intuitiva. Somente quando o vocabulário da biologia molda-se segundo os princípios da teoria da comunicação e da cibernética, a noção de erro chega a sua maturidade.

Desde 1909, o termo "erro hereditário" é usado para designar alterações inatas do metabolismo. Esse termo que ainda repousava na engenhosidade de uma metáfora foi promovido a uma consistente analogia, depois dos estudos célebres de Crick e Watson sobre a dupla hélice do DNA, divulgados por volta de 1953. Como se sabe, as pesquisas sobre a dupla hélice enviaram a biologia para o plano molecular, através de um vocabulário originalmente criado pela teoria da informação. Noções, como código, mensagem e tradução orientaram e ainda orientam o entendimento dos mecanismos de transmissão da hereditariedade.

Não tardou para que a patologia fosse enviada ao plano molecular através do arsenal teórico da teoria da informação. Assim, uma doença, como anemia falciforme, segue uma lógica, que não é mais a da degradação, mas a da má interpretação do código, já que se desenvolve pela substituição de um único aminoácido na cadeia da proteína que forma a hemoglobina, tornando-a disforme. $\mathrm{O}$ problema reside, portanto, na transmissão de informação, na decodificação das mensagens inscritas no material he- 
reditário. Sendo um problema de comunicação, a saúde é a correção genética e enzimática e a patologia resulta de uma confusão, de uma má interpretação.

\section{Determinação e indeterminação do passado}

$\mathrm{Na}$ atualidade, vemos as pesquisas que apostavam no determinismo genético sofrerem inúmeras críticas, cujo eixo comum é uma descrença na concepção de programa genético (LEITE, 2006). Essa noção, cuja interseção com a cibernética, a teoria da informação e os sistemas computacionais é bastante evidente, atribui ao patrimônio genético um poder de determinação no organismo, como se o indivíduo estivesse virtualmente construído e o desenvolvimento nada mais fizesse do que atualizar uma realidade potencial.

Supondo que a existência humana (e de todo vivente) não passe de uma obediência a um texto já escrito, os defensores da noção de programa genético tratam a vida como repetição de uma memória. Haveria um fluxo unidirecional do código para a mensagem, que implica na produção de uma substância química (proteína) que serve para a constituição de características físicas e mentais. Haveria também uma correspondência estrita entre o gene e o organismo, com cada item do código (um gene) fabricando uma proteína e essa produzindo um traço orgânico. Essa crença não é incompatível com a intervenção tecnológica. As biotecnologias poderiam intervir sobre essa memória, mas o fariam exatamente porque o passado se repete com tal força no presente que se torna necessário uma intervenção artificial.

Na primeira década do nosso século, um motivo de peso implicou revisões no determinismo genético. Parte considerável dos pesquisadores envolvidos no Projeto Genoma Humano calculava obter um grande número de genes, uma quantidade próxima a de 100.000 proteínas, produzidas no organismo humano e envolvidas nas características físicas individuais. Com a obtenção do número aproximado de $30.000^{6}$ ao final da pesquisa, tornou-se mais difícil sustentar que somos uma repetição da memória genética. A tônica da pesquisa recai sobre o modo como os genes funcionam e não tanto como eles se distribuem. Complementando a pesquisa sobre o mapeamento do Genoma (genômica estrutural), se enfatiza a compreensão do funcionamento dos genes (genômica funcional). Reorientação que define o que pode ser chamado de pós-genômica, campo de estudos onde impera a crítica ao determinismo genético.

Criticar o determinismo genético, no entanto, não impede que formas de normatizar o indivíduo, de construir identidades, se propaguem. Uma das vertentes de aplicação médica do conhecimento sobre o Genoma consiste na estimativa de patologias prováveis, ou seja, cujo risco de desenvolvimento está assinalado geneticamente. A ideia de risco genético só faz sentido a partir de dois conjuntos: um biológico, formado por anomalias cromossômicas ou por erros de transcrição, e outro, por

\footnotetext{
${ }^{6}$ As duas grandes pesquisas de sequenciamento estimaram de forma diferente o número de genes. A Celera Genomics, empresa privada liderada por Craig Venter, apostou em algo entre 26.000-38.000, enquanto o Projeto Genoma Humano, em um número entre 30.000 e 40.000 .
}

fatores ambientais que podem desencadear processos que conduzem a patologias. É na interseção desses conjuntos que determinadas práticas médicas objetivam se instalar, tomando como alvo a predição.

Predizer tem um sentido ligeiramente diferente de prevenir. A prevenção implica intervir ou diagnosticar precocemente doenças já formadas, como por exemplo, detectar através do exame do líquido amniótico uma trissomia do cromossomo 23 no feto em gestação. Já predizer é, segundo o médico Jacques Ruffié (1993), uma detecção de enfermidades que ainda não se formaram e que talvez jamais venham a se formar. Essa dimensão de incerteza, onde só existem probabilidades, não deixa de ser celebrada como uma importante promessa da medicina. Como um exemplo da extensão da proposta preditiva ao cotidiano, na edição 2019 da revista Veja, valoriza-se o enfraquecimento do determinismo genético. Se os genes não nos determinam, as possibilidades de transformar nossas mentes e corpos são imensas: "a descoberta de que os hábitos e o estilo de vida mudam o comportamento dos genes está na raiz de uma revolução extraordinária para a medicina", destaca a reportagem, que prossegue apontando o aprimoramento terapêutico: “ela ajudará na criação de remédios personalizados, capazes de alterar o genoma para deter o desenvolvimento de doenças e de transtornos psíquicos" (CARELLI, 2009, p. 87).

Para nos transformarmos, no entanto, é preciso conhecer nossa constituição orgânica, o perfil genético a partir do qual os tratamentos personalizados serão construídos e indicados. Curioso jogo entre dissolução da identidade e sua reconstrução: sabendo o que somos, podemos ser outro, divergir de nós mesmos. Nada desse jogo se aparenta à identidade moderna, onde a figura emblemática era o homossexual, ou seja, um indivíduo cujo passado e desejo definem o que ele é; tanto que ainda acreditamos que caso nosso desejo não se revele, parte fundamental de nós mesmos é mutilada. Mas pouco a pouco, ao invés de refletir sobre o que se é, torna-se fundamental transformar a si tecnologicamente. O passado agora não é mais imutável, uma memória ou programa estáticos, e seu peso é diminuído de forma a originar transformações. Ainda assim, exerce seu peso, visto que para ser transformado deve ser conhecido e definido de modo a determinar perfis de risco.

Esse jogo entre dissolução e reconstrução da identidade aparece de forma semelhante na literatura. Deleuze (1998) nos lembra que a finitude não é mais o eixo central das formas de conhecer e intervir sobre o|a homem|mulher. Ao invés da morte, transformada pela medicina e pela literatura do século XIX em meio de acesso à condição humana, os saberes e tecnologias se distribuem segundo outra configuração epistemológica. Nessa configuração, os limites do|a homem|mulher, do seu corpo são suspensos, na medida em que a medicina faz mais do que curar patologias, aprimorando estados normais e, com as biotecnologias, produz novos seres.

$\mathrm{Na}$ linguagem, a experiência literária, assim como o DNA, partiria de um conjunto limitado de textos para produzir uma infinidade de discursos. Tanto a literatura, 
quanto o DNA, mostram que os estudos sobre as vicissitudes da linguagem apontam para tensões constantes entre o poder e a resistência. Através de nossa reflexão, analisamos essas tensões indicando, como a história do livro e a história do corpo estão associadas a uma tentativa de captura e imposição de ordem nas possíveis vias de interpretação do texto escrito, do corpo e, por conseguinte, do código genético. Contra a produção de uma infinidade de discursos possíveis, se estabelece a ordem como freio à proliferação discursiva.

Assim, observamos como as interpretações do texto escrito e do código genético estão associadas à vontade de verdade, à ordenação e à imposição da melhor leitura. Mas assinalamos também como a literatura e as novas leituras do gene associadas à crise do determinismo genético estão do lado daquilo que escapa à ordem nas searas da linguagem: o seu indeterminismo constitutivo.

\section{Referências}

ALMEIDA, L. P. Escrita e leitura: a produção de subjetividade na experiência literária. Paraná: Juruá, 2009.

ALMEIDA, L. P.; DO EIRADO, A. A morte... ou a outra vida? Psicologia Clínica. Rio de Janeiro, v. 15, n. 1, p. 17-27, 2003.

CANGUILHEM, G. O normal e o patológico. Tradução de Maria Thereza Redig de Carvalho Barrocas. Rio de Janeiro: Forense Universitária, 1995.

CARELli, G. Genética não é espelho. Veja, São Paulo, n. 2109, p. 86-96, abr. 2009.

CAVALLO, G. Entre volumen e codex, a leitura no mundo romano. In: CAVALLO, G.; CHARTIER, R. (Org.). História da leitura no mundo ocidental. São Paulo: Ática, 1998. v. 1, p. 71-102.

CAVALLO, G.; CHARTIER, R. (Org.). Introdução. In: História da leitura no mundo ocidental. São Paulo: Ática, 1998. v. 1, p. 5-40.

CHARTIER, R. A ordem dos livros: leitores, autores e bibliotecas na Europa entre os séculos XIV e XVIII. Brasília: UnB, 1999.

CHARTIER, R. Cultura escrita, literatura e História. Rio Grande do Sul: Artmed, 2001.

DELEUZE, G. Crítica e Clínica. Rio de Janeiro: Editora 34, 1997.

DELEUZE, G. Foucault. Rio de Janeiro: Brasiliense, 1998.

EAGLETON, T. A ideia da cultura. São Paulo: Unesp, 2005.

ECO, U. O nome da rosa. Rio de Janeiro: Record, 1986.

ELIAS, N. O Processo civilizador: formação do Estado e civilização. Rio de Janeiro: J. Zahar, 1993. v.2.

FOUCAULT, M. As palavras e as coisas. São Paulo: Martins Fontes, 1987.

FOUCAULT, M. Nietzsche, la généalogie, l'histoire. In: DEFERT, D.; EWALD, F. (Dir.). Dits et écrits II (1970-1975). Paris: Gallimard, 1994. p. 136-156.

FOUCAULT, M. A verdade e as formas jurídicas. Tradução de R. Machado \& E. J. Morais. Rio de Janeiro: PUC Rio; Nau, 1996.
FOUCAULT, M. A loucura, a ausência da obra. In: MOTTA, M. B. (Org.). Problematização do Sujeito: Psicologia, Psiquiatria e Psicanálise. Rio de Janeiro: Forense Universitária, 1999a. Coleção Ditos \& Escritos, v. 1, p. 190-198.

FOUCAULT, M. Loucura, literatura, sociedade. In: MOTTA, M. B. (Org.). Problematização do Sujeito: Psicologia, Psiquiatria e Psicanálise. Rio de Janeiro: Forense Universitária, 1999b. Coleção Ditos \& Escritos, v. 1, p. 210-234.

FOUCAULT, M. A loucura e a sociedade. In: MOTTA, M. B. (Org.). Problematização do Sujeito: Psicologia, Psiquiatria e Psicanálise. Rio de Janeiro: Forense Universitária, 1999c. Coleção Ditos \& Escritos, v. 1, p. 235-242.

FOUCAULT, M. Linguagem e literatura. In: MACHADO, R. Foucault, a filosofia e a literatura. Rio de Janeiro: J. Zahar, 2000. p. 137-174.

FOUCAULT, M. Prefácio à transgressão. In: MOTTA, M. B. (Org.). Estética: Literatura e Pintura, Música e Cinema. Rio de Janeiro: Forense Universitária, 2001a. Coleção Ditos \& Escritos, v. 3, p. 28-46.

FOUCAULT, M. A Linguagem ao infinito. In: MOTTA, M. B. (Org.). Estética: Literatura e Pintura, Música e Cinema. Rio de Janeiro: Forense Universitária, 2001b. Coleção Ditos \& Escritos, v. 3, p.47-59.

FOUCAULT, M. O Que é um Autor? In: MOTTA, M. B. (Org.). Estética: Literatura e Pintura, Música e Cinema. Rio de Janeiro: Forense Universitária, 2001c. Coleção Ditos \& Escritos, v. 3, p. 264-298.

FOUCAULT, M. História da Sexualidade: a vontade de saber. Rio de Janeiro: Graal, 2002. v.1.

FOUCAULT, M. O Nascimento da Clínica. Rio de Janeiro: Forense Universitária, 2004.

GINZBURG, C. Mitos, emblemas e sinais: morfologia e história. São Paulo: Companhia das Letras, 2007.

GRAFTON, A. O leitor humanista. In: CAVALLO, G.; CHARTIER, R. (Org.). História da leitura no mundo ocidental. São Paulo: Ática, 1999. v. 2, p. 5-46.

HABERMAS. J. Hermeneutique ou analyse. In: APEL, K-O et al. Un siècle de philosofie. Paris: Gallimard, 2000. p. 177-230.

HAMESSE, J. O modelo escolástico da leitura. In: CAVALLO, G.; CHARTIER, R. (Org.). História da leitura no mundo ocidental. São Paulo: Ática, 1998. v. 1, p. 123-146.

HAROCHE, C. Fazer dizer, querer dizer. São Paulo: Hucitec, 1992.

HAROCHE, C.; COURTINE, J. J. Histoire du Visage, XVIdébut XIX siècle. Paris: Rivages, 1988.

JACOB, F. A lógica da vida: uma história da hereditariedade. Rio de Janeiro: Graal, 1983.

KATZENSTEIN, U. E. A origem do livro: da idade da pedra ao advento da invenção tipográfica no Ocidente. São Paulo: Hucitec, 1986.

KUNDERA, M. L'art du roman. Paris: Gallimard, 1986.

LE BRETON, D. Adeus ao corpo. Rio de Janeiro: Vozes, 2007.

LEITE, M. As promessas do Genoma. São Paulo: Unesp, 2006.

LEROI-GOURHAN, A. O gesto e a palavra: memórias e ritmos. São Paulo: Perspectiva, 2002. v. 2. 
LÉVY, P. As tecnologias da inteligência: o futuro do pensamento na era da informática. São Paulo: Editora 34, 1993.

MATELLART, A.; MATTELART, M. História das teorias da comunicação. São Paulo: Loyola, 2008.

MAUSS, M. As técnicas do corpo. In: . Sociologia e Antropologia. São Paulo: Cosac \& Naif, 2007. p. 399-422.

NIETZSCHE, F. A gaia ciência. São Paulo: Cia. das letras, 2001.

PARKES, M. Ler, escrever, interpretar o texto, práticas monásticas na Alta Idade Média. In: CAVALLO, G.; CHARTIER, R. (Org.). História da leitura no mundo ocidental. São Paulo: Ática, 1998. v. 1, p. 103-122.

ROSE, N. Politics of life itself: biomedicine, power and subjectivity in the twenty first century. London: Routdledge, 2007.

RUFFIÉ, J. Naissance de la Médicine Prédictive. Paris: Odile Jacob, 1993.

SAENGER, P. Ler nos séculos finais da Idade Média. In: CAVALLO, G.; CHARTIER, R. (Org.). História da leitura no mundo ocidental. São Paulo: Ática, 1998. v. 1, p. 147-184.

SANT'ANNA, B. Corpos de passagem: ensaios sobre a subjetividade contemporânea. São Paulo: Estação Liberdade, 2001.

SLOTERDIJK, P. Regras para um parque humano: uma resposta à carta de Heidegger sobre o humanismo. São Paulo: Estação Liberdade, 2000.

SVENBRO, J. A Grécia arcaica e clássica: a invenção da leitura silenciosa. In: CAVALLO, G.; CHARTIER, R. (Org.). História da leitura no mundo ocidental. São Paulo: Ática, 1998. v. 1, p. 41-69.

TROUSSON, R. Romance e libertinagem no século XVIII na França. In: NOVAES, A. (Org.). Libertinos e libertários. São Paulo: Cia. das letras, 1996. p. 165-182.

Recebido em: 18 de janeiro de 2015 Aceito em: 30 de junho de 2017 